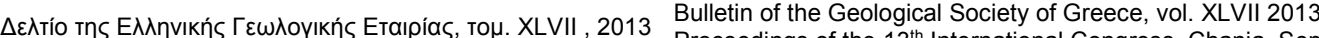
$\triangle 1$ Proceedings of the $13^{\text {th }}$ International Congress, Chania, Sept.

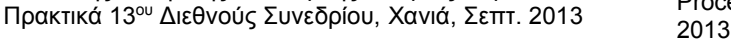

\title{
EVALUATION OF CRETACEOUS LIMESTONES FROM THE AITOLOAKARNANIA PROVINCE (WESTERN GREECE) FOR THEIR USE AS ROAD AGGREGATES IN TERMS OF THEIR CONTENT IN SWELLING CLAY MINERALS
}

\author{
Mpalatsas I. ${ }^{1}$, Rigopoulos I. ${ }^{1}$, Tsikouras B. ${ }^{1,2}$ and Hatzipanagiotou K. ${ }^{1}$ \\ ${ }^{1}$ University of Patras, Department of Geology, Section of Earth Materials, 265 00, Patras \\ mpalatsas@upatras.gr,rigopoul@upatras.gr,v.tsikouras@upatras.gr, \\ k.hatzipanagiotou@upatras.gr \\ ${ }^{2}$ University of Brunei Darussalam, Department of Petroleum Geoscience, Jalan Tungku Link, \\ Gadong BE1410, Bandar Seri Begawan, Brunei Darussalam
}

\begin{abstract}
The aim of this paper is to assess the suitability of a significant number of carbonate rocks from the Aitoloakarnania province (Western Greece) for their use as road construction aggregates, in terms of their content in swelling clay minerals. The study focuses on Cretaceous limestones from the Olonos-Pindos zone. Detailed petrographic analysis and the sand equivalent and methylene blue tests are carried out, in order to estimate the quantity of swelling clay minerals in aggregate particles. Special emphasis is given on correlating the results of the sand equivalent and methylene blue tests, as well as on the relationships between these engineering parameters and the petrographic data. The results are evaluated in accordance with the Greek and International suitability Standards for road construction aggregates. Although the results of the sand equivalent test indicate the suitability of the studied samples, the results of the methylene blue test imply that they are not suitable for use in all applications of road construction. Hence, it is proved that the methylene blue test is of fundamental importance for the determination of the lithotypes which are suitable for use as road aggregates in various applications.
\end{abstract}

Key words: Carbonate rocks, Olonos-Pindos zone, aggregates, sand equivalent, methylene blue.

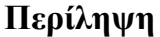

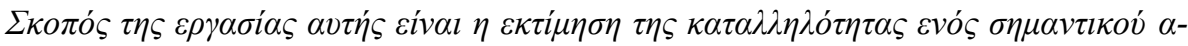

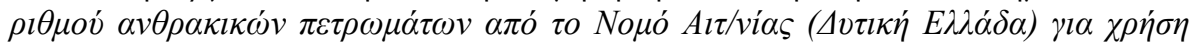

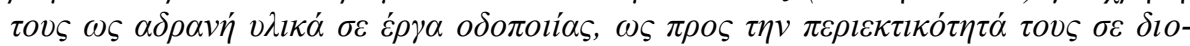

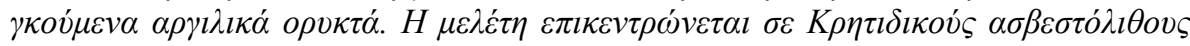

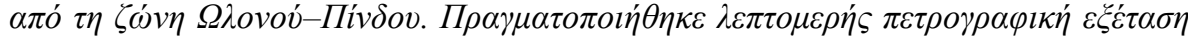

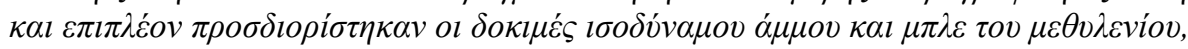

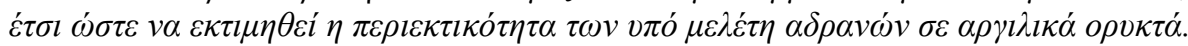

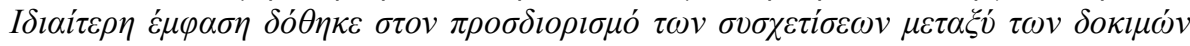

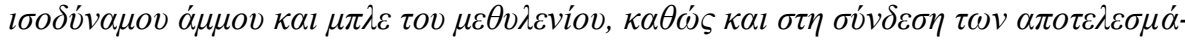

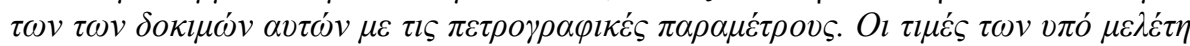

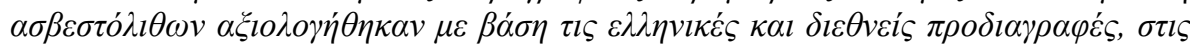

$\underline{\text { XLVII, No } 3-1990}$ 


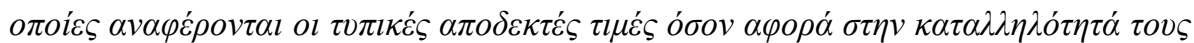

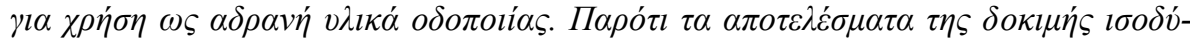

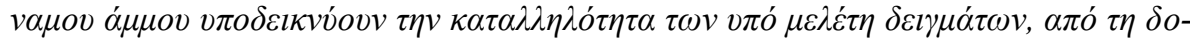

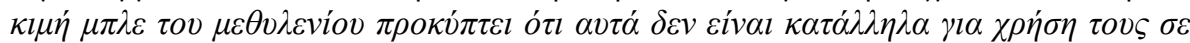

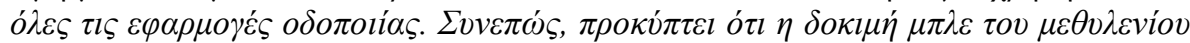

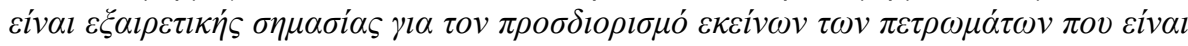

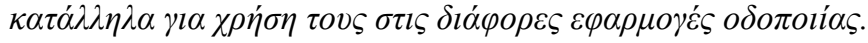

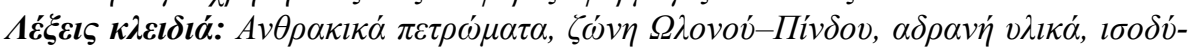

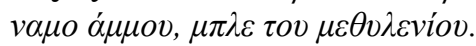

\section{Introduction}

The increasing demand for crushed rock aggregates in various applications and especially the requirement for hard aggregates in numerous infrastructure works of Greece, have increased the necessity for the detection of carbonate rocks which are suitable for the production of aggregates used for: bases and sub-bases, improvement layers, bituminous mixtures, concrete and embankments. The suitability of aggregate materials depends on their various physicomechanical properties, as well as on their content in clay minerals. In terms of grain size, clay refers to particles less than $2 \mu \mathrm{m}$ in diameter, while clay minerals are hydrous aluminium phyllosilicates. Swelling clay minerals are considered to be the minerals of the smectite group. The latter absorb water and tend to swell, causing significant problems in the unbound road layers. Clay minerals also reduce the cohesion of bituminous mixtures, due to the fact that they destroy the adhesion between asphalt and aggregate particles (Smith and Collis, 2001; Nikolaides et al., 2007).

The sand equivalent test is used for the determination of clay-like fines in aggregates; however the methylene blue test is applied to obtain an assessment of the quantity of swelling clay minerals of the smectite type in a sample of aggregate. These tests are carried out in aggregates used in both unbound and bound road layers. This paper investigates the suitability of 51 carbonate rock samples from the Aitoloakarnania province (Western Greece) for their use as road construction aggregates, based on their mineralogical-textural features and on the results of the sand equivalent and methylene blue tests.

\section{Geological Setting}

The carbonate rocks of the Olonos-Pindos zone (Aitoloakarnania province, Western Greece) (Fig. 1), cover a total area of $417 \mathrm{~km}^{2}$. They comprise part of the lower unit (thickness more than 1000 $\mathrm{m}$ ) of the Olonos-Pindos zone, which includes pelagic limestones of Triassic to Upper Cretaceous age. These limestones are intercalated with radiolarites of Middle Jurassic to Lower Cretaceous, while their thickness varies from 200 to $400 \mathrm{~m}$ (Katsikatsos, 1992; Mountrakis, 1985). The Upper Cretaceous limestones, which comprise the upper part of this lower unit, are whitish limestones, gray micritic limestones with veins filled with secondary calcite and red limestones.

The studied area (Fig. 1) and especially the Upper Cretaceous carbonate rocks cover an area of 301 $\mathrm{km}^{2}$, which corresponds to the $72.35 \%$ of the overall carbonate formations of the Olonos-Pindos zone. The rock slopes of the area exhibit layers up to $35 \mathrm{~cm}$ thick and are cut by joints with opening up to $3-4 \mathrm{~cm}$. These lithologies are characterized by intense fracturing and folding.

\section{Petrography}

The petrographic study of the Upper Cretaceous carbonate rocks of the Olonos-Pindos zone (Aitoloakarnania province) includes the macroscopic and microscopic examination of 51 samples. These samples were collected from representative localities of quarry faces or natural slopes, with a view to be fresh and to represent the full variability of the quarry products.

XLVII, No 3 - 1991 


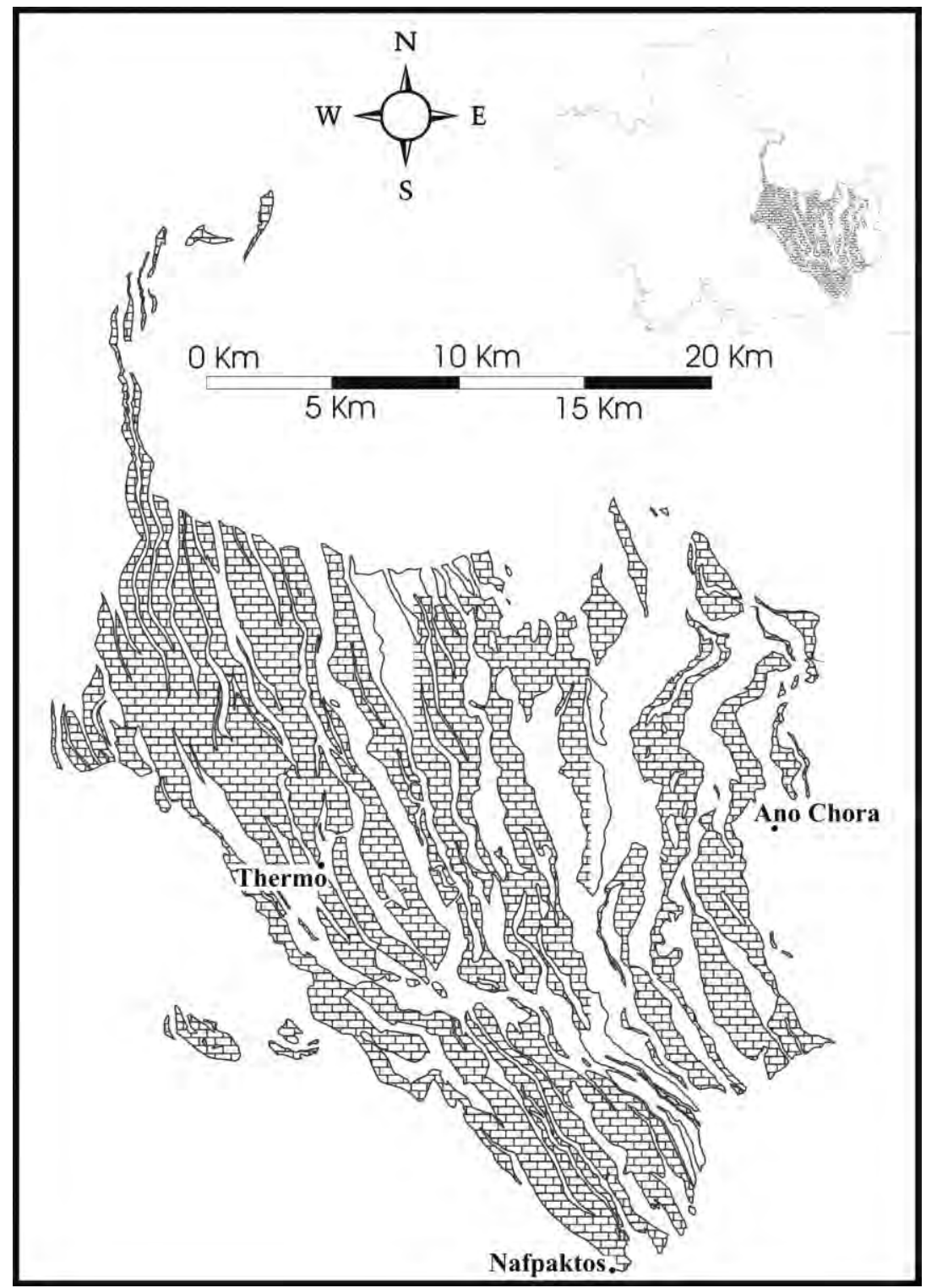

Figure 1 - Simplified geological map of the studied Upper Cretaceous limestones of the Olonos-Pindos zone (Aitoloakarnania province).

Macroscopically, the studied rock types show a dense network of sparitic veins and their colour is whitish to gray, except for samples AT2B, AT6C, AT8C, AT9B, AT17C, AT19B, AT22B and AT42B, which have a red colour. The samples were collected based on petrographic criteria, which significantly determine their quality as aggregate material (Zarif and Tuğrul, 2003; Tsikouras et al., 2005; Pomonis et al., 2007).

The microscopic examination, which was carried out using polarized microscopy at the Research Laboratory of Minerals and Rocks, Department of Geology, University of Patras, indicated that the samples are micritic or sparitic microcrystalline limestones with veins filled with secondary calcite. Quartz crystals, as well as the phyllosilicate minerals muscovite and/or biotite are also present. The dominance of bioclasts is obvious, however many samples also contain lithoclasts, endoclasts or opaque minerals. The Upper Cretaceous limestones can be classified according to the grains/matrix ratio and their content in endoclasts, lithoclasts or bioclasts, as follows: 
(a) Fossiliferous-micrites according to Folk (1962) or mudstones according to Dunham (1962) with a joint system which cuts a micritic matrix. The joints have been filled with sparitic calcite (Fig. 2a). Additionally, there is a low content of fossils in a uniform, dark coloured micritic matrix. Joints with a thickness up to $0.3 \mathrm{~mm}$, which are filled with secondary, microcrystalline calcite, are also present. Moreover, areas with channel or fracture porosity are observed (Fig. 2b).

(b) Sparse biomicrites according to Folk (1962) and wackestones/packstones according to Dunham (1962). They are biomicritic limestones, which contain pieces of broken fossils, as well as sizeable and well preserved bioclasts (skeletal remains of planktonic foraminifera). In addition, the characteristic fossils of Upper Cretaceous Calpionella (Fig. 2c) and Globotruncana (Fig. 2d) occur in a micritic matrix. The joints of this lithology are filled with microcrystalline calcite, while the styloliths are filled with Fe-oxides and clay minerals (Fig. 2d).

(c) Packed biomicrites according to the classification scheme of Folk (1962) and packstones according to the classification scheme of Dunham (1962). These rocks contain bioclasts in a proportion of more than $50 \%$ (Fig. 2e, f), as well as carbonate grains which are surrounded by a micritic matrix.

(d) Sorted-unsorted intrabiosparites according to Folk (1962) and grainstones according to Dunham (1962). They comprise lithoclasts, endoclasts, bioclasts (Fig. 2g, h) and opaque minerals in a sparite cement, while the micritic matrix is absent. These rocks are characterized by the presence of isometric, coarse grains of calcite, which contain abundant lithoclasts, endoclasts and fossils (Fig. 2h). The porosity is primarily channel-type, filled with sparite material. Stylolithic or fenestral porosity filled with Fe-oxides and/or clay minerals can also be observed.

\section{Geometrical Properties}

The suitability of the studied limestones for their use as aggregate material in highway engineering was assessed based on the results of the sand equivalent and methylene blue tests. Subsequently, the results were evaluated in accordance with the Greek and International suitability Standards for road construction aggregates (Tables 1,2).

The sand equivalent test (SE) defines the relative proportions of clay-like fines in aggregates passing ASTM Sieve No $4(4.75 \mathrm{~mm})$, since an excess of clays is usually detrimental to the performance of any aggregate (Hveem, 1953). This test was carried out in accordance with ASTM D2419. As can be seen in Table 3, the SE values of the studied rocks are $\geq 60 \%$; hence they are suitable for use in base and sub-base layers, bituminous mixtures for wearing courses and cold bituminous mixtures. Specifically, the SE values range as follows:

- Fossiliferous micrites: $60-77 \%$

- Biomicrites: $60-79 \%$

- Sparites: $68-81 \%$

The methylene blue test (MB), which is applied to obtain an assessment of the quantity of swelling clay minerals of the smectite type in a sample of aggregate, was determined according to the procedure described in EN 933-9. This test was determined in the fine aggregate fraction of 0-0.125 $\mathrm{mm}$ (MBf), taking into account that it gives results with better repeatability (Nikolaides et al., 2007). The MBf values of the studied rocks range as follows:

- Fossiliferous micrites: $8.6-26.6 \mathrm{~g} / \mathrm{kg}$

- Biomicrites: $6.6-20.0 \mathrm{~g} / \mathrm{kg}$

- Sparites: 4.3 - $9.3 \mathrm{~g} / \mathrm{kg}$ 

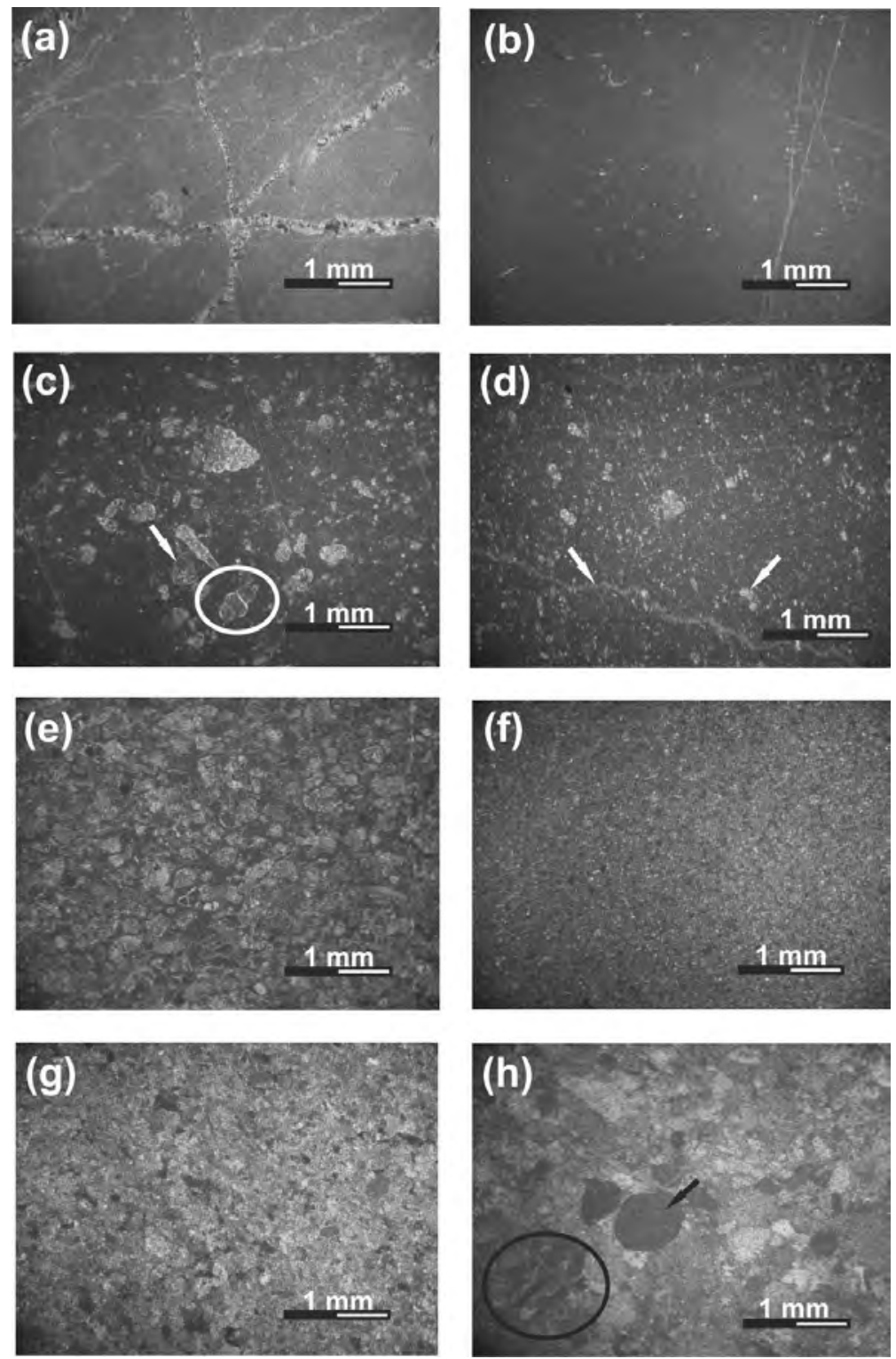

Figure 2 - (a) Fossiliferous micrite: joints filled with sparry calcite in a micritic matrix (Nicols+); (b) Fossiliferous micrite: sparsely scattered fossils in a micritic matrix with fracture porosity (Nicols+); (c) Sparse biomicrite/wackestone: pieces of broken calpionellids (arrow) and foraminifera (ellipse) (Nicols+); (d) Sparse biomicrite/wackestone: moderate participation of fossils in a rock type with fracture porosity. Fe-oxides and clay minerals fill the stylolith at the lower part of the field of view (left arrow). The right arrow shows a Globotruncana (Nicols + ); (e) Packed biomicrite/packstone: abundant bioclasts $(>50 \%)$ in a micritic matrix (Nicols+); (f) Packed biomicrite/packstone: bioclasts and opaque minerals (Nicols+); (g) Sorted intrabiosparite/ grainstone: participation of lithoclasts-bioclasts (Nicols+); (h) Unsorted intrabiosparite/grainstone: participation of endoclasts (arrow) and fossils (ellipse)

(Nicols+). 
Table 1 - Permissible sand equivalent (SE) values.

\begin{tabular}{|l|c|}
\hline \multicolumn{1}{|c|}{ Aggregates for: } & $\begin{array}{c}\text { SE (\%) } \\
\text { Greek Specifications }\end{array}$ \\
\hline Bituminous mixtures for wearing courses & $>55$ \\
\hline Bituminous base courses & $>50$ \\
\hline Unbound base courses & $>50$ \\
\hline Unbound sub-base courses & $>40$ \\
\hline Cold bituminous mixtures for wearing courses & $>50$ \\
\hline Cold bituminous mixtures for base layers & $>45$ \\
\hline
\end{tabular}

Table 2 - Permissible methylene blue (MBf) values.

\begin{tabular}{|l|c|c|}
\hline Aggregates for: & $\begin{array}{c}\text { Specifications (MBf) } \\
\text { NF XP P 18-540 }\end{array}$ & $\begin{array}{c}\text { Greek Specifications } \\
\text { (MBf) }\end{array}$ \\
\hline Base and sub-base layers & $\leq 10^{(3)}$ & $\leq 10^{(1)}$ \\
\hline Bituminous bases & $\leq 10^{(3)}$ & $\leq 10$ \\
\hline Bituminous bound layers & $\leq 10^{(3)}$ & $\leq 10$ \\
\hline Wearing courses & $\leq 10^{(3)}$ & $\leq 10$ \\
\hline Concrete & $\leq 10^{(3)}$ & \\
\hline $\begin{array}{l}\text { Cold bituminous mixtures } \\
\text { Micro-surfacing layers }\end{array}$ & $\leq 7$ or $\leq 8 \mathrm{MBf}^{(2)}$ & \\
& $\leq 10 \quad \mathrm{MBf}^{(2)}$ & \\
\hline
\end{tabular}

(1) Egnatia Odos S.A.

(2) Specifications of other countries

(3) French specifications

(e.g. linear, logarithmic) and it was observed that the logarithmic model gives the higher $R^{2}$ values. As can be seen in Figure 3, different trends were calculated for fossiliferous micrites, biomicrites and sparites, which are described by the following equations:

$$
\begin{gathered}
S E=-12.962 \times \ln M B f+105.79, \quad \mathrm{R} 2=0.5666 \quad \text { (Fossiliferous micrites) } \\
S E=-9.0277 \times \ln M B f+94.156, \quad \mathrm{R} 2=0.3255 \quad \text { (Biomicrites) } \\
S E=-10.157 \times \ln M B f+91.664, \quad \mathrm{R}^{2}=0.3853 \quad \text { (Sparites) }
\end{gathered}
$$

The calculated $R^{2}$ values indicate weak to moderate negative correlations between SE and MBf. The insignificant correlations between these geometrical parameters can be attributed to the different nature of the sand equivalent and methylene blue tests.

Based on the petrographic classification according to Folk (1962) and Dunham (1962) and the dispersion of the results of the geometrical properties (Fig. 3), the studied carbonate rocks can be further grouped into:

A) Fossiliferous micrites

$1^{\text {st }}$ Group: Samples AT7A, AT10A and AT11A with MBf values varying between 8.6 and $9.6 \mathrm{~g} / \mathrm{kg}$ and $\mathrm{SE}$ values ranging from 76 to $77 \%$.

$2^{\text {nd }}$ Group: Samples AT6D, AT8A, AT13A, AT13B, AT17B, AT17C, AT20B and AT42B with MBf values from 13.0 to $26.6 \mathrm{~g} / \mathrm{kg}$ and SE values from 60 to $76 \%$. The substantially higher MBf values of the samples of this group, compared to those of the first group, are due to the clay minerals which fill the styloliths of the samples of the second group. 
Table 3 - Results of the Methylene Blue and Sand Equivalent of the studied rock samples from the Olonos-Pindos zone (Aitoloakarnania province).

\begin{tabular}{|c|c|c|c|}
\hline Sample & Rock Type & Methylene Blue (g/kg) & Sand Equivalent (\%) \\
\hline AT6D & Fossiliferous micrite & 21.0 & 64 \\
\hline AT7A & Fossiliferous micrite & 9.6 & 76 \\
\hline AT8A & Fossiliferous micrite & 26.6 & 68 \\
\hline AT9B & Fossiliferous micrite & 19.6 & 63 \\
\hline AT10A & Fossiliferous micrite & 8.6 & 76 \\
\hline AT11A & Fossiliferous micrite & 9.0 & 77 \\
\hline AT13A & Fossiliferous micrite & 13.0 & 76 \\
\hline AT13B & Fossiliferous micrite & 16.6 & 70 \\
\hline AT17B & Fossiliferous micrite & 16.0 & 77 \\
\hline AT17C & Fossiliferous micrite & 17.6 & 65 \\
\hline AT20B & Fossiliferous micrite & 16.6 & 73 \\
\hline AT42B & Fossiliferous micrite & 20.3 & 60 \\
\hline AT2A & Biomicrite & 13.3 & 71 \\
\hline AT2B & Biomicrite & 16.3 & 68 \\
\hline AT4A & Biomicrite & 10.7 & 70 \\
\hline AT6A & Biomicrite & 8.0 & 77 \\
\hline AT6C & Biomicrite & 10.6 & 67 \\
\hline AT7B & Biomicrite & 8.0 & 76 \\
\hline AT8C & Biomicrite & 16.6 & 68 \\
\hline AT11C & Biomicrite & 8.3 & 72 \\
\hline AT12A & Biomicrite & 6.6 & 77 \\
\hline AT12B & Biomicrite & 10.0 & 78 \\
\hline AT14A & Biomicrite & 10.0 & 69 \\
\hline AT15A & Biomicrite & 11.6 & 71 \\
\hline AT16A & Biomicrite & 16.6 & 60 \\
\hline AT18B & Biomicrite & 11.0 & 73 \\
\hline AT18C & Biomicrite & 15.0 & 75 \\
\hline AT19A & Biomicrite & 12.3 & 77 \\
\hline AT19B & Biomicrite & 14.0 & 68 \\
\hline AT22A & Biomicrite & 9.0 & 73 \\
\hline AT22B & Biomicrite & 20.0 & 72 \\
\hline AT22C & Biomicrite & 10.0 & 71 \\
\hline AT48 & Biomicrite & 8.3 & 77 \\
\hline AT49A & Biomicrite & 10.0 & 79 \\
\hline AT49B & Biomicrite & 15.0 & 70 \\
\hline AT54 & Biomicrite & 10.0 & 76 \\
\hline AT2C & Sparite & 8.6 & 77 \\
\hline AT4B & Sparite & 5.6 & 76 \\
\hline AT6B & Sparite & 7.6 & 68 \\
\hline AT8B & Sparite & 9.3 & 67 \\
\hline AT9A & Sparite & 5.6 & 68 \\
\hline AT10B & Sparite & 8.6 & 70 \\
\hline AT11B & Sparite & 8.3 & 68 \\
\hline AT14B & Sparite & 9.0 & 72 \\
\hline AT15B & Sparite & 6.6 & 70 \\
\hline AT16B & Sparite & 9.3 & 71 \\
\hline AT17A & Sparite & 4.3 & 81 \\
\hline AT18A & Sparite & 5.0 & 77 \\
\hline AT19C & Sparite & 6.3 & 69 \\
\hline AT20A & Sparite & 5.0 & 76 \\
\hline AT42A & Sparite & 9.3 & 68 \\
\hline
\end{tabular}

$\underline{\text { XLVII, No } 3-1996}$ 


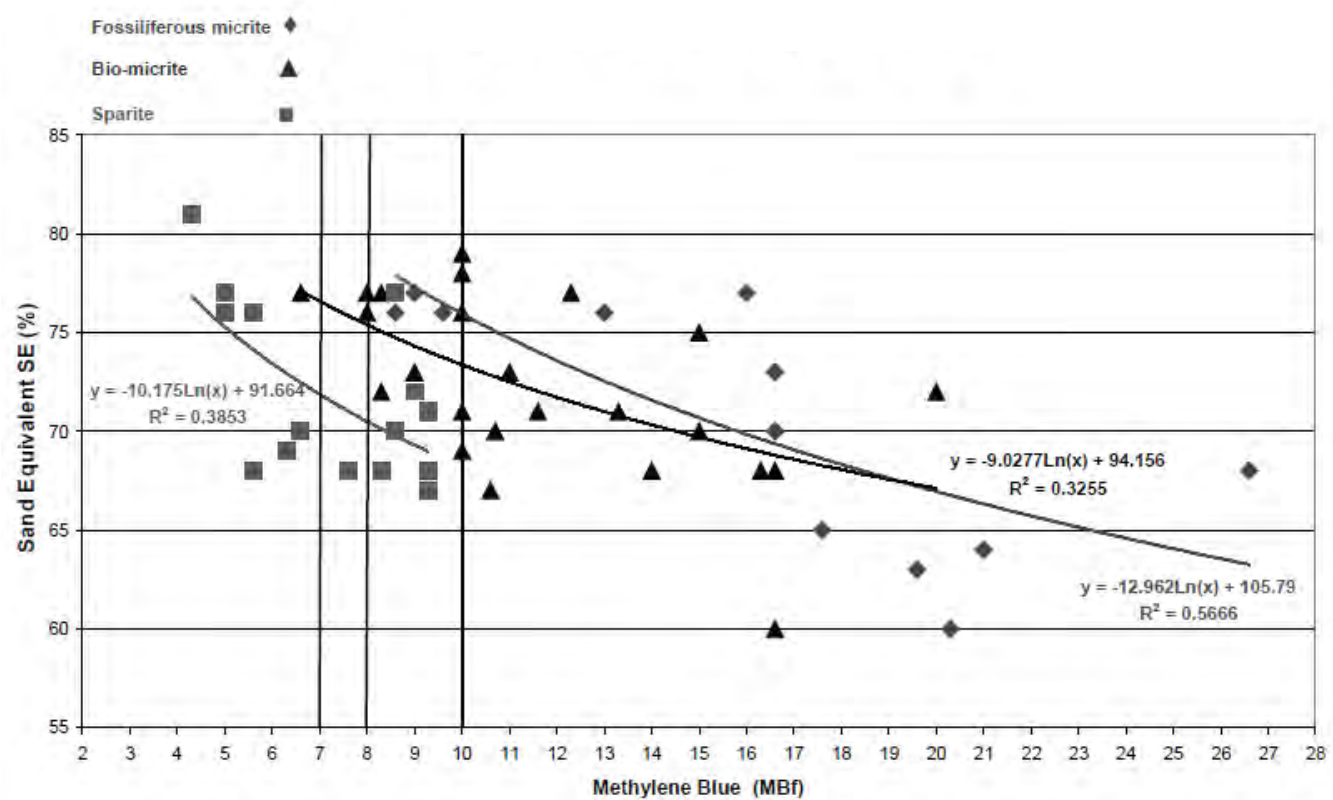

Figure 3 - Correlation between methylene blue (MBf) and sand equivalent (SE) of the stud-

B) Biomicrites ied limestones.

$1^{\text {st }}$ Group: Samples AT12A, AT6A, AT11C, AT22A and AT7B whose MBf values range from 6.6 to $9.0 \mathrm{~g} / \mathrm{kg}$ and SE values from 72 to $77 \%$.

$2^{\text {nd }}$ Group: Samples AT2A, AT2B, AT4A, AT6C, AT8C, AT12B, AT14A, AT14B, AT15A, AT16A, AT18B, AT18C, AT19A, AT19B, AT22B, AT48, AT49A, AT49B, AT54 and AT22C with $\mathrm{MBf}$ values ranging from 8.3 to $16.6 \mathrm{~g} / \mathrm{kg}$ and SE values ranging from 60 to $79 \%$. The stylolith or channel porosity of these samples has been filled with clay material and this is considered to be the reason for their higher MBf values.

C) Sparites

$1^{\text {st }}$ Group: Samples AT2C, AT4B, AT17A, AT18A and AT20A with MBf varying from 4.3 to 8.6 $\mathrm{g} / \mathrm{kg}$ and SE ranging from 72 and $81 \%$. The higher MBf value of sample AT2C compared to the other samples is attributed to its stylolithic porosity, which is filled with Fe-oxides and clay minerals.

$2^{\text {nd }}$ Group: Samples AT6B, AT8B, AT6C, AT9A, AT12B, AT11B, AT14B, AT15B, AT16B, AT19C and AT42A with MBf ranging between 5.6 and $9.3 \mathrm{~g} / \mathrm{kg}$ and SE varying from 67 to $73 \%$. The higher MBf and lower SE values of these samples, compared to those of the first group, are assigned to the fact that the samples of the second group have higher percentage of stylolythic and channel porosity, filled with clay material.

\section{Discussion}

The petrographic features, as well as the degree of tectonic deformation and porosity of rocks are determinative parameters for their quality as aggregate material (Hartley, 1974; Kazi and AlMansour, 1980; Al-Jassar and Hawkins, 1991; Smith and Collis, 2001; Jensen et al., 2010). Additionally, the geometrical properties of aggregates play an important role in the estimation of aggregate performance in-service (Nikolaides et al., 2007; Rigopoulos et al., 2013). The results of this study bring new details to the understanding of the interrelations between the sand equivalent test, 
the methylene blue test and the petrographic characteristics of carbonate rocks. The suitability of the studied samples for their use as aggregates in road construction is also assessed.

The petrographic examination indicated that the carbonate rocks of this study can be grouped into: (a) fossiliferous micrites, (b) biomicrites, and (c) sparites. The geometrical properties of these lithotypes seem to be highly controlled by their microscopic features. Those samples which have stylolithic and/or channel porosity, filled with clay material, tend to have lower sand equivalent and higher methylene blue values, implying the interdependence among petrography and engineering parameters. Similar relationships have been referred by various researchers (e.g. Miskovsky et al., 2004; Kondelchuk and Miskovsky, 2008; Rigopoulos et al., 2013).

Regarding the correlation between sand equivalent and methylene blue, regression analysis indicated that there is no significant relationship between these geometrical parameters due to the different nature of the two tests. Similar results have also been referred by Nikolaides et al. (2007).

The values of the sand equivalent test for the studied Upper Cretaceous limestones are $\geq 60 \%$; hence they are all considered suitable for use in base and sub-base layers, bituminous mixtures for wearing courses and cold bituminous mixtures. However, the sand equivalent test defines the relative proportions of clay-like fines in aggregates; thus the results of the methylene blue test, which determines the quantity of swelling clay minerals, should also be taken into consideration. Samples AT2C, AT14B, AT16B, AT10B, AT42A, AT8B, AT11B, AT11C, AT14B, AT7A, AT14B, AT10A, AT22A, AT7A and AT11A have MBf values $\leq 10 \mathrm{~g} / \mathrm{kg}$ and $\geq 8 \mathrm{~g} / \mathrm{kg}$, so they are suitable for use in base and sub-base road layers and bituminous mixtures for wearing courses. Samples AT4B, AT6A, AT6B, AT7B, AT9A, AT12A, AT15B, AT17A, AT18A, AT19C and AT20A, which show $\mathrm{MBf}$ values $\leq 8 \mathrm{~g} / \mathrm{kg}$, can also be used as aggregates in cold bituminous mixtures. On the other hand, samples AT12B, AT14A, AT22C, AT49A and AT54 are near the MBf limit of 10 $\mathrm{g} / \mathrm{kg}$ and exhibit relatively high sand equivalent values (SE: 69-79\%). The rest of the samples (AT2A, AT2B, AT4A, AT6C, AT6D, AT8A, AT8C, AT9B, AT13A, AT13B, AT15A, AT16A, AT17B, AT17C, AT18B, AT18C, AT19A, AT19B, AT22B, ATA22B, AT42B and AT49B), whose $\mathrm{MBf}$ values range from 10.6 to $26.6 \mathrm{~g} / \mathrm{kg}$, are unsuitable for use in road construction due to the high proportion of swelling clay minerals in their porosity.

\section{Conclusions}

The carbonate lithotypes of this study can be grouped into: (a) fossiliferous micrites, (b) biomicrites, and (c) sparites. Their geometrical parameters seem to be significantly controlled by their mineralogical and textural characteristics. The samples which have stylolithic and/or channel porosity, filled with clay material, tend to have lower sand equivalent and higher methylene blue values. This indicates that the knowledge of the petrographic features of rocks is of great importance for the estimation of their engineering behaviour.

There is insignificant relationship between the results of the sand equivalent and methylene blue tests, which is assigned to the different nature of these two geometrical properties.

The results of the sand equivalent test indicate that the studied samples are suitable for use as aggregates in base and sub-base layers, bituminous mixtures for wearing courses and cold bituminous mixtures; however the results of the methylene blue test imply that a number of the studied limestones are not suitable for use in road construction. Thus, it is proved that the methylene blue test is of fundamental significance for the determination of the lithotypes which are suitable for use as road aggregates in various applications.

\section{Acknowledgements}

Critical reviews by Professor Dr. Georgia Pe-Piper and an anonymous reviewer are gratefully appreciated.

$\underline{\text { XLVII, No } 3-1998}$ 


\section{References}

Al-Jassar S. and Hawkins A.B. 1991. The Carboniferous Limestone of the Bristol area: a review of the influence of the lithology and chemistry on its use as a geomaterial, Q. J. Eng. Geol. Hydrogeol., 24, 143-158.

Dunham R.J. 1962. Classification of carbonate rocks according to depositional texture, in Ham, W.E. (ed), Classification of carbonate rocks: Am. Assoc. Petroleum Geologists Memoir, 108-121.

Folk R.L. 1962. Spectral subdivision of limestone types. In Ham, W.E., ed., Classification of carbonate rocks: Am. Assoc. Petroleum Geologists, Memoir 1, 62-84.

Hartley A. 1974. A review of the geological factors influencing the mechanical properties of road surface aggregates, Q. J. Eng. Geol., 7, 69-100.

Hveem F.N. 1953. Sand Equivalent test for control of materials during construction, Highway Research Board Proceedings, 32, Washington.

Jensen L.R.D., Friis H., Fundal E., Møller P. and Jespersen M. 2010. Analysis of limestone micromechanical properties by optical microscopy, Eng. Geol., 110, 43-50.

Katsikatsos G. 1992. Geology of Greece, University of Patras, 451 pp.

Kazi A. and Al-Mansour, Z.R. 1980. Influence of geological factors on abrasion and soundness characteristics of aggregates, Eng. Geol., 15, 195-203.

Kondelchuk D. and Miskovsky K. 2008. Determination of the test methods sensitive to free mica content in aggregate fine fractions, J. Mater. Eng. Perform., 18, 282-286.

Miskovsky K., Taborda Duarte M., Kou S.Q. and Lindqvist, P.-A., 2004. Influence of the mineralogical composition and textural properties on the quality of coarse aggregates, J. Mater. Eng. Perform., 13, 144-150.

Mountrakis D. 1985. Geology of Greece, University Studio Press, Thessaloniki, 207 pp.

Nikolaides A., Manthos E. and Sarafidou M. 2007. Sand equivalent and methylene blue value of aggregates for highway engineering, Foundations of Civil and Environmental Engineering, 10, 111-121.

Pomonis P., Rigopoulos I., Tsikouras B., and Hatzipanagiotou, K. 2007. Relationships between petrographic and physicomechanical properties of basic igneous rocks from the Pindos ophiolitic complex, NW Greece, Bull. Geol. Soc. Greece, XXXVII, 947-958.

Rigopoulos I., Tsikouras B., Pomonis P. and Hatzipanagiotou K. 2013. Correlations between petrographic and geometrical properties of ophiolitic aggregates from Greece, Bull. Eng. Geol. Env. (in press).

Smith M.R. and Collis L. 2001. Aggregates: Sand Gravel and Crushed Rock aggregates for Construction Purposes, Geological Society, London Eng. Geol., Sp. Publ. 17, 339 p.

Tsikouras B., Pomonis P., Rigopoulos, I., and Hatzipanagiotou, K., 2005. Investigation for the suitability of basic ophiolitic rocks from Mikrokleisoura, Grevena, for their use as antiskid aggregates and railway ballast, Proc. $2^{\text {nd }}$ Congress of the Committee of Economic Geology, Mineralogy, and Geochemistry of the Geological Society of Greece, 347-356.

Zarif I.H. and Tuğrul A., 2003. Aggregate properties of Devonian limestones for use in concrete in Istanbul, Turkey, Bull. Eng. Geol. Env., 62, 379-388. 